\title{
School dysfunction in 5 to 19 year old children with only motor disabilities seen at a reference hospital in Argentina
}

\author{
Mercedes Rodríguez Celin, M.D. ${ }^{a}$, María Silvina Bevilacqua, M.D. ${ }^{b}$, Cecilia Shimoji, M.D. ${ }^{b}$ \\ and Virginia Fano, M.D. ${ }^{a}$
}

\begin{abstract}
Although children with only motor disabilities have no intellectual disabilities and should attend a regular school, in the pediatric practice it has been observed that there is a high level of heterogeneity in their education. The objective of our study was to establish the prevalence of school dysfunction in children with only motor disabilities who are seen in a reference hospital, and explore if there are socio-demographic, medical and/or school outcome measures related to school dysfunction. The study was cross-sectional, observational, analytical, and comparative.

Two hundred and eighty-eight 5 to 19 year old patients with only motor disabilities wereincluded (September 2011-February 2012). Of them, $25 \%$ (72) had school dysfunction. A history of surgery $(\mathrm{OR}=10.8$ [4.23-27.57]), a poor maternal education $(\mathrm{OR}=4.20$ [1.18-14.9]), chronic pain $(\mathrm{OR}=3.62$ [1.77-7.40]), and the use of a wheelchair $(\mathrm{OR}=3.01[1.48-6.10])$ were found to be statistically significant risk factors for school dysfunction. In our sample, being an only child $(\mathrm{OR}=0.09$ [0.01-0.54]) was a protective factor.

Key words: children with disabilities, orthopedic surgery, education, school dysfunction, chronic pain.
\end{abstract}

http:/ / dx.doi.org/10.5546/aap.2014.eng.245

\section{INTRODUCTION}

A child with a motor disability is defined as that with any motor impairment due to a bone, joint, muscle and/or nervous impairment that, to a varying degree, limits the performance of activities as done by other children the same age. ${ }^{1}$ Disability is an evolving concept and is the result of the interaction between a person's deficiency and obstacles, such as physical barriers and prevailing attitudes that prevent that person's full participation in society. The more hurdles, the more disabled a person becomes.

a. Department of Growth and Development.

b. Palliative Care Unit.

Hospital Nacional de Pediatría "Prof. Dr. Juan P. Garrahan,"

Buenos Aires, Argentina.

E-mail address:

Mercedes Rodríguez Celin, M.D.: cucarc@yahoo.com

Conflict of Interest: None.

Received: 6-28-2013

Accepted: 11-27-2013
Childrenwith only motor disability (OMD) do not suffer cognitive-intellectual impairments, and so they are expected to access and remain in a regular education environment. However, in our daily practice, as pediatricians, a high level of heterogeneity has frequently been observed in the education of children with OMD.

The objective of our study was to establish the prevalence of school dysfunction in children with OMD who are seen in a reference hospital, and explore if there are socio-demographic, medical and/or educational outcome measures related to dysfunction.

\section{POPULATION AND METHODS}

The study was cross-sectional, observational, and analytical. All 5 to 19 year old patients with OMD seen at the Hospital Garrahan between September 2011 and February 2012 were included.

Those with a current or past diagnosis of cancer, and patients with OMD who had an underlying disease associated with an intellectual impairment and/or a diagnosis of learning disability or severe sensory disorder such as deafness or blindness were excluded.

In all cases, caregivers were asked to give their informed consent and participants older than 15 years old were asked to give their assent.

The protocol was approved by the Ethics Committee and Research Review Committee of the hospital.

Patients were consecutively enrolled at the Growth and Development office, the Traumatology and Orthopedics office, the Spinal Unit and the multipurpose day hospital.

Data were collected using a specially-designed record during interviews and from medical records.

The dependent outcome measure was the presence or absence of school dysfunction (SDys). In this study, SDys was defined as the presence of some of the following situations: missing a mandatory school year, having a home teacher and/ or prolonged absenteeism ( $>2$ months), or attending a special education school.

Independent outcome measures were classified as follows: 
Socio-demographic outcome measures: age, sex, unmet basic needs (UBNs) ${ }^{4}$ health insurance, disability certificate, number of siblings (large family, >3 siblings), maternal education (incomplete primary school was considered a poor maternal education level).

Medical outcome measures: diagnosis, use of a wheelchair/orthosis/cast, number of medical visits, history of hospitalization, history of surgery between March and December of all school years since the initiation of mandatory education, chronic pain, ${ }^{5}$ height (extremely low height: $\leq-3 \mathrm{SD}){ }^{6}$

School outcome measures: public/private school, need of classroom caregiver, percentage of absenteeism, need to modify school facilities (ramp, elevator, change of classroom location, adapted classroom/bathroom furniture), ${ }^{7}$ difficulty in getting a vacancy and/or need to change schools because of the underlying disease, attendance to mandatory education prior to occurrence of disability, history of repetition of any school year.

Statistical analysis: It was calculated that 220 subjects were required to estimate a $20 \% \pm 4 \%$ school dysfunction prevalence based on clinical practice estimations. Risk factors were assessed using a multivariate analysis, considering the presence of 10-20 subjects with a positive event for modeling each factor.

\section{RESULTADOS}

Out of 293 available patients with OMD, five did not provide their consent, so a total of 288 patients with OMD were included.

Table 1 describes their diagnoses.

The prevalence of SDys in the OMD pediatric population was found to be $25 \%$ (72 patients): of them, $29(40.28 \%)$ had missed a mandatory school year; $46(63.89 \%)$ had a home teacher o prolonged absenteeism, and $4(5.55 \%)$ attended a special education school. Some patients $(9.72 \%)$ had more than one type of SDys.

In turn, 62 patients $(21.50 \%)$ had a history of having repeated a school year.

\section{Socio-demographic, medical and school outcome measures}

Mean age was 11.31 years old (SD 3.48). In the included population, $55(19 \%)$ had started mandatory education with no disability at all.

Table 2 describes the socio-demographic, medical and school characteristics of the assessed population by presence or absence of school dysfunction.
Table 3 presents school facility modifications requested by patients.

The multivariate analysis showed that a history of surgery, chronic pain, poor maternal education and use of a wheelchair were independent factors associated with the presence of SDys. In addition, being an only child a protective factor against dysfunction (Table 4).

\section{DISCUSSION}

Disabled children are the ones who suffer most unmet education needs. As referred by Blanco in her report on equity and inclusion, many countries in the region have no reliable statistics regarding the education of disabled children, and those which do, show a high percentage of disabled children with no education at all. ${ }^{8}$

As per Jiménez' study, approximately $37 \%$ of disabled people have suffered problems in their integration to a regular education system. ${ }^{9}$

The Argentine National Education Law establishes the right to an inclusive education. However, the 2003 national survey conducted on disabled people ${ }^{10}$ evidenced that $80 \%$ of children with disabilities aged 3 to 17 years old attend a school. In relation to the level of education attained, it was observed that most disabled people either finish primary school or have an incomplete secondary education. ${ }^{11}$

Also, as per the 2009 report by the InterAmerican Commission on Human Rights, 10\% of children with disabilities aged 3 to 14 years old never attended a school. ${ }^{12}$ These percentages are much higher than the national average for disabled children, whose education rate at 14 years old was $98 \%$ in 2006 . However, data in both publications are not broken-down by type of disability or type of school. SDys was found in $25 \%$ of this population; this implies that one every four children suffers restrictions to access and remain in a regular school, although they

TABLE 1. Diagnosis leading to only motor disabilities in the studied population

\begin{tabular}{lc}
\hline Diagnosis & N (\%) \\
\hline Skeletal dysplasia & $106(37 \%)$ \\
Congenital musculo skeletal malformation & $66(23 \%)$ \\
Acquired musculo skeletal disease & $57(20 \%)$ \\
Spinal disease & $18(6 \%)$ \\
Hypophosphatemic rickets & $11(4 \%)$ \\
Marfan syndrome & $8(3 \%)$ \\
Neuromuscular disease & $6(2 \%)$ \\
Other diseases & $16(5 \%)$ \\
\hline
\end{tabular}


TABLE 2. Overall description and comparison between children with and without school dysfunction by socio-demographic, medical and school outcome measures

\begin{tabular}{|c|c|c|c|}
\hline $\begin{array}{l}\text { Socio-demographic outcome } \\
\text { measures N (\%) }\end{array}$ & $\begin{array}{c}\text { With school } \\
\text { dysfunction } 72(25 \%)\end{array}$ & $\begin{array}{c}\text { Without school } \\
\text { dysfunction } 216(75 \%)\end{array}$ & $\begin{array}{l}\text { p-value and } \\
\text { OR (CI) }\end{array}$ \\
\hline Unmet basic needs 49 (17\%) & $16(22.2)$ & $33(15.2)$ & NS $(0.17)$ \\
\hline Male $152(53 \%)$ & $38(52.7)$ & $114(52.7)$ & NS (1) \\
\hline No health insurance 101 (35\%) & $26(36.1)$ & $75(34.7)$ & NS $(0.83)$ \\
\hline Disability certificate 149 (52\%) & $41(56.9)$ & $108(50)$ & NS (0.30) \\
\hline Large family $81(28 \%)$ & $26(36.1)$ & $55(25.4)$ & NS (0.09) \\
\hline Only child $40(14 \%)$ & $2(2.7)$ & $38(17.6)$ & $0.002 \mathrm{OR}=0.13(0.01-0.54)$ \\
\hline Poor maternal education $17(6 \%)$ & $9(12.5)$ & $8(3.7)$ & $0.006 \mathrm{OR}=3.71(1.20-11.50)$ \\
\hline $\begin{array}{l}\text { Medical outcome measures } \\
\mathrm{N}(\%)\end{array}$ & $\begin{array}{c}\text { With school } \\
\text { dysfunction } 72(25 \%)\end{array}$ & $\begin{array}{c}\text { Without school } \\
\text { dysfunction } 216(75 \%)\end{array}$ & $\begin{array}{l}\text { p-value and } \\
\text { OR (CI) }\end{array}$ \\
\hline Congenital disease 215 (75\%) & $52(72.2)$ & $163(75.4)$ & NS (0.58) \\
\hline Use of a wheelchair $72(25 \%)$ & $36(50)$ & $36(16.6)$ & $<0.0001 \mathrm{OR}=5(2.66-9.33)$ \\
\hline Use of a cast $123(43 \%)$ & $45(62.5)$ & $78(36.1)$ & $<0.0001 \mathrm{OR}=2.94(1.64-5.33)$ \\
\hline Use of orthosis 135 (47\%) & $48(67)$ & $87(40.3)$ & $<0.0001 \mathrm{OR}=3.22(1.76-5.94)$ \\
\hline Number of medical visits, median (lQR) & $21(10.5-49.5)$ & $12(5-24)$ & $<0.0001$ \\
\hline History of hospitalization 179 (62\%) & $64(88.9)$ & $115(53.2)$ & $<0.0001 \mathrm{OR}=12.61(4.43-49)$ \\
\hline History of surgery $169(59 \%)$ & $64(88.8)$ & $105(48.1)$ & $<0.0001 \mathrm{OR}=9.81(4.21-26.35)$ \\
\hline Chronic pain $83(29 \%)$ & $33(45.8)$ & $50(23.1)$ & $<0.0001 \mathrm{OR}=2.80(1.53-5.10)$ \\
\hline Extremely low height $63(23 \%)$ & $16(22.2)$ & $47(21.75)$ & $0.94 \mathrm{OR}=1.02(0.55-1.91)$ \\
\hline $\begin{array}{l}\text { School outcome measures } \\
\mathrm{N}(\%)\end{array}$ & $\begin{array}{c}\text { With school } \\
\text { dysfunction } 72(25 \%)\end{array}$ & $\begin{array}{c}\text { Without school } \\
\text { dysfunction } 216(75 \%)\end{array}$ & $\begin{array}{l}\text { p-value and } \\
\text { OR (CI) }\end{array}$ \\
\hline Public school 209 (72\%) & $60(83.3)$ & $149(68.9)$ & $0.01 \mathrm{OR}=2.24(1.10-4.88)$ \\
\hline Absenteeism percentage & 4.80 & 2.31 & $<0.0001$ \\
\hline Classroom caregiver 33 (11\%) & $14(19.4)$ & $19(8.8)$ & 0.01 \\
\hline \multicolumn{4}{|l|}{ Need of installation } \\
\hline modifications $131(45.6 \%)$ & $44(61.1)$ & $87(40.2)$ & $0.0015 \mathrm{OR}=2.14(1.34-4.36)$ \\
\hline Difficulty getting a vacancy $23(8.4 \%)$ & $8(11.1)$ & $15(6.9)$ & NS $(0.31)$ \\
\hline Need to changes school $29(10.6 \%)$ & $14(19.4)$ & $15(6.9)$ & 0.004 \\
\hline
\end{tabular}

TABLE 3. School installation modifications requested and obtained by patients with only motor disabilities

\begin{tabular}{lcc}
\hline Installation modification & Requested modification N (\%) & Obtained modification N (\%) \\
\hline Ramp & $77(27 \%)$ & $25(9 \%)$ \\
Change of classroom location & $50(17 \%)$ & $37(13 \%)$ \\
Change of bathroom furniture & $27(9 \%)$ & $17(6 \%)$ \\
Change of classroom furniture & $24(8 \%)$ & $14(5 \%)$ \\
Elevator & $11(4 \%)$ & $5(2 \%)$ \\
\hline
\end{tabular}


TABLE 4. Results of multivariate analysis

\begin{tabular}{lcc}
\hline $\begin{array}{l}\text { Independent outcome measure } \\
\text { associated with school dysfunction }\end{array}$ & Odds ratio & 95\% confidence interval \\
\hline Surgery & 10.80 & $4.23-27.57$ \\
Poor maternal education & 4.20 & $1.18-14.9$ \\
Chronic pain & 3.62 & $1.77-7.40$ \\
Use of a wheelchair & 3.01 & $1.48-6.10$ \\
Only child & 0.09 & $0.01-0.50$ \\
\hline
\end{tabular}

The multivariate model had an adequate fit (Hosmer-Lemeshow test: 0.61 ) and an area under the ROC curve of 0.85 (CI: $0.80-$ $0.90)$.

should not. It should be mentioned that these children have difficulties to get a vacancy in a regular school or need to change schools because of their motor impairment. The absence of ramps and having classrooms located in upper floors were common findings. Other potential hurdles observed were not having a disability certificate and/or the lack of health insurance.

The fact that having a history of surgery was a main risk factor should be taken as a warning sign of the need to work preventively towards a post-surgery school reintegration.

The presence of undetected chronic pain is a signal of alarm regarding this symptom's silent and disturbing process.

Inclusive education is intended to make the right to a quality education a reality, which is the basis for a more just and equal society. As pediatricians, we know these children are the ones with most unmet education needs and the problems their families deal with. We believe that this study provides data on the difficulties faced by this group to access and remain in a regular school, although it is limited because it does not assess school performance. A better understanding on this issue will allow us to avoid missing the opportunity to encourage education during our consultations.

\section{CONCLUSIONS}

In this study, a $25 \%$ prevalence of SDys was observed in children with OMD. Risk factors related to SDys included having a history of surgery, chronic pain, use of a wheelchair, and poor maternal education. Being an only child was a protective factor against SDys.

\section{Acknowledgments}

We would like to thank the members of the Department of Growth and Development at the Hospital Garrahan for helping us with the project development.

To Dr. Susana Rodríguez for her valuable collaboration editing this manuscript.

To the Fundación Garrahan for funding the research grant.

\section{REFERENCES}

1. Martín Caro L, Rosa A, Montero I. Las necesidades educativas especiales del niño con deficiencia motórica. Madrid: CNREE. MEC; 1990.

2. Jiménez Buñuales MT, Gonzáles Diego P, Martín Moreno JM. Clasificación Internacional del Funcionamiento, de la Discapacidad y dela Salud (CIF) 2001. Rev Esp Salud Pública 2002;76(4):271-9.

3. Muñoz V. El derecho a la educación de las personas con discapacidades. Informe del Relator Especial sobre el derecho a la educación. Aplicación de la Resolución 60/251 de la Asamblea General, del 15 de marzo de 2006. A/ $\mathrm{HRC} / 4 / 29 ; 2007$.

4. INDEC. La pobreza en la Argentina: Asociación de características de los hogares con mediciones de la pobreza y diseño de un indicador compuesto de Necesidades Básicas Insatisfechas. $2^{\text {da }}$ ed. Buenos Aires: INDEC; 1985;1(Suppl 1).

5. Mc Caffery M, Beebe A. Pain: Clinical Manual for Nursing Practice. Baltimore: U.V. Mosby Company; 1993.

6. Comité Nacional de Crecimiento y Desarrollo. Sociedad Argentina de Pediatría. Guías para la Evaluación del Crecimiento. $2^{\text {da }}$ ed; Buenos Aires: SAP; 2001.

7. Consejo nacional de coordinación de políticas sociales. Programa de Accesibilidad para ámbitos educativos. [Accessed on: April 3, 2014]. Available at: http://www. conadis.gov.ar/Programa $\% 20$ Ley $\% 20$ de $\% 20$ Cheques $\% 20$ $2014 \% 20$ Programa $\% 20$ de $\% 20$ Accesibilidad $\% 20$ para $\% 20$ ambitos\%20educativos.pdf.

8. Blanco R. La equidad y la inclusión social: uno de los desafíos de la Educación y la Escuela hoy. Rev Electrón iberoam calid, efic cambio educ 2006;4(3):1-15.

9. Jiménez A, Huete A. La discriminación por motivos de discapacidad. Madrid: CERMI. 2002. [Accessed on: 
April 3, 2014]. Available at: http://www.cermi.es/ es-Es/ColeccionesCermi/Cermi.es/Lists/Coleccion/ Attachments/76/3disciminacion.pdf.

10. INDEC-UNICEF, Sistema Integrado de indicadores Sociales y Económicos sobre la niñez y la adolescencia en la Argentina (SIISENA); elaboración sobre la base de procesamientos especiales suministrados por la Primera Encuesta Nacional de Personas con Discapacidad 2002-2003, complementaria al Censo 2001.

11. Beech J, Larrondo M. La inclusión educativa en la Argenti- na de hoy. Definiciones, logros y desafíos a futuro. Argentina. Taller regional preparatorio sobre educación inclusiva. América Latina, Regiones Andina y ConoSur. Buenos Aires: UNESCO; 2007.

12. Muñoz V. Derecho a la educación de las personas con discapacidad en América Latina y el Caribe. Informe para la Comisión Interamericana de Derechos Humanos. Noviembre, 2009. [Accessed on: April 3, 2014]. Available at: www. asdown.org/descargas/educacion_personas_con_discapacidad_informacion.pdf 